\title{
Subjectively perceived change in consumption along the living standards in old ages
}

\author{
Réka Hegedüs - Klaudia Rádóczy \\ University of Pécs
}

\section{THE AIMS OF THE PAPER}

The aim of our research is to provide a picture of the conditions for providing the income background necessary for old age, the spending habits of the 50 plus age group, and to illustrate how the old ages goup of our survey, the elderly age group we survey perceives changes in their spending in the last 10-year.

\section{METHODOLOGY}

We used a representative personal survey with 500 Hungarian people. This survey was made in February 2020 on a targeted sample of the Hungarian population aged 50-70. In the analysis method, we used cluster formation, because we tried to identify groups showing different consumption changes based on the consumption categories of the Hungarian Central Statistical Office.

\section{MOST IMPORTANT RESULTS, NEW FINDINGS}

The results show that the people who participated in the survey had little perception of a change in their spending compared to their life 10 years before. On the other hand, our retirement income in old age may lag far behind the income in active, working years, so we can assume that if the significant decline in income did not affect consumption patterns, old-age income may be supplemented by savings in old age.

\section{EMPIRICAL IMPLICATIONS OF THE RESEARCH}

The clusters that we made shows well that the spendings of the 50-plus age group are also significant for the economy as a whole. The types of their expenditures is diverse and there is a lot of items that they would not necessarily be able to afford from an average income funded by the pension scheme. The characteristics of the clusters also show that there is a positive relationship between financial awareness (planning spending, exploring sales) and age. In our oppinion this is the reason why financial awareness education, the communications about this is very important. The financial management of households can be incorporated into the education of children from an early age.

Keywords: saving for old age, ability to save, aging, propensity to save, spending in old age

Acknowledgments: This research was partially supported by the Human Resource Development Operational Programme, grant No.: EFOP-3.6.1-16-2016-00004 "Comprehensive developments at the University of Pécs for the implementation of intelligent specialization"

DOI: 10.15170/MM.2021.55.KSZ.02.02 


\section{INTRODUCTION}

The phenomenon of the aging societies of the 21st century also poses a challenge to the pension systems of national economies and to the self-sufficiency and propensity of individuals to save. Dividend-based pension schemes are in many cases unsustainable, so there is increasing pressure on the individual to obtain fiscal security in old age. The literature distinguishes two important factors in terms of self-care: human nature and the motivational capacity of the pension system for selfcare in old age. The problems of pension systems are well known, but savings for self-care in old age are not typical for young people entering the labor market, but can only be observed at older cohorts. The reason of this phenomenon may be the lack of the ability to save in the case of young people, we think that they spend their earned income on housing expenses and possible savings. Short-term preferences are also characterized by the need for housing and existential stability at a young age. However, in the case of old age cohorts, both of the housing expenditures and costs of existential stability are declining, and they can feel the need for fiscal security after their active period.

There is a positive relationship between the degree of financial awareness and age. In the case of the older cohorts (age group 50 plus), the development of financial awareness already involves self-control, fear about economic uncertainty and pessimism about the functioning of the economy. The 50-plus age group makes a large part of the retail wealth of national economies and their asset portfolios are very complex. After the end of the active work period, people in the economy, especially those with a high level of education, would like to hold the standard of living achieved with as few deductions as possible. However, spending from earned income can be very varied, but it is significant for the economy as a whole.

The aim of our study is to present the conditions for providing the income background necessary for living in old age, and the spending habits of the 50 plus age group. In the first step of our research, we summarize the literature on saving for self-sufficiency in old age and the willingness to do so, followed by studies on the financial situation of old age. After that, we present the living standards of Hungarian households and the situation of people with old age. The main added value of the study is a cluster analysis, in which we look for the answer to how the spending habits of the respondents in the $50-70$ age cohort have changed in the last 10 years.

\section{LITERATURE REVIEW}

Although the problems of pension systems in national economies and the fact of an aging social composition are known, the propensity to save for self-sufficiency in old age is highly variable. However, in order to maintain the standard of living during the active period, it is almost always necessary to supplement the income provided by the state pension system from own resources. The co-existence of these in most cases avoids a drastic change in the previous spending structure. Ongena \& Zalewska (2018), examining the propensity to save for retirement, concluded that pension systems are often incapable of providing sufficient incentives for people to save for retirement. However, the problems of Hungary's current pension system call for the widest possible spread of individual-level savings for pension purposes. The problem is that a significant proportion of households do not take appropriate steps for self-care for old age in time (Lusardi 2001). However, the lack of individual-level savings increases uncertainty after the active work period (Starr 2006). The fiscal uncertainty of the retirement years is also significantly influenced by the amount of the pension and the general wealth situation (Blaked 2004), as maintaining a normal standard of living is desirable for most people. As Boldizsár (2016) points out in a Household Finance and Consumption Survey database, the main asset of Hungarian households is real estate, which consumes significant savings and future incomes even in active life, this is the reason why people just later start raising the capital needed to maintain a normal standard of living in old age.

It is important to emphasize that the attitude towards risk also influences savings decisions, if we do not only want to secure our old age - over 65 (Posza 2018) - by raising capital. As the retirement period approaches, their willingness to take risks also seems to change, for the most part they choose low-risk or risk-free forms of investments. Cocco et al. (2005) demonstrated that as households approach old age, they prefer less risky transactions in their investments, however, Choi \& Robertson (2020) highlights that this change in risk behavior is determined by the time remaining until retirement years. Kuti - Schepp (2020), in their work synthesizing the international literature, also concluded that risk avoidance is increased in older cohorts.

Human factors include the effects of short-term thinking and financial awareness on the propensity to save. Several surveys show that financial awareness is also low in developed countries with excel- 
lent education systems (Lusardi \& Mitchell 2006, 2007, 2011, Lusardi et al. 2014, Atkinson \& Messy 2011, van Rooij et al. 2011, Dushi \& Honig 2015, Lusardi \& Tufano 2015). Horváthné Kökény and Széles (2014) in their study examined savings decisions in Hungary. In their results, they distinguished 4 types of households, however, they unanimously believe that during the high school and high school years, the financial approach should be consciously presented to the population, which also includes saving and spending habits. According to Stiglitz (2013), good quality of financial education is also one of the cornerstones of financial awareness, and the state has a key role to play in building it.

Stolper (2018) shows that there is a negative relationship between financial awareness and age, while there is a positive relationship among education, income and wealth status, and financial awareness. Younger generations generally do not place much emphasis on savings and only start making their own conscious financial decisions later. On the other hand, in general, the financial awareness of those with higher incomes or better wealth is also stronger. Financial awareness has a positive relationship between wealth and the quality of financial decisions. In their studies, Almenberg and Säve-Söderbergh (2011), Fornero and Monticone (2011), and Sekita (2011) consistently came to the conclusion that financially conscious people rely less on counselors. This may be due to the rejection of additional costs or the nature of the individual qualification. According to Cobb-Clark et al. (2016), it is less effective for retirement savers to plan self-care based on counseling, but Nardi et al. (2009) found a relationship between expected age and willingness to save, as did Bloom (2006) earlier. Demirgüç-Kunt et al. (2016) found that older adults, the more educated, and financially conscious people have a higher propensity to save for retirement.

Biljanovska \& Palligkinis (2017) emphasize the importance of environmental factors and point out that the pension system only works well if it conveys a sufficient amount of information to savers, allowing them to be able to plan and track the development of their savings. However, Hungary's current funded pension system is almost unsuitable for this. According to Banyár (2019), on the other hand, investing the pension system in human capital would effectively remedy the problems of the state-maintained pension system.

The willingness to save for self-sufficiency increases as individuals age. Due to the global phenomenon of population aging, the 50 plus market is the fastest growing and richest market in developed countries (Dann 2007). The purchasing power of today's older consumers exceeds not only their predecessors, but also that of other market segments (such as younger consumers). In addition, individual's decisions about saving money or spending collectively make the economy change (Katona 1975). It also follows that the study of the consumption and saving habits of the elderly is not a new phenomenon.

In terms of savings, researchers have incorporated into their models the psychological factors of savings, such as self-control, fear of economic uncertainty, and pessimism about the economy. Lunt \& Livingstone's 1991 article on self-control, which is the basis of early theories, believed that resistance to the temptation to spend allows savings; which ability develops with age and schooling (Wärneryd 1989). Despite the positive cultural meaning of thrift, Keynes (1936) considered spending to be rational, while saving was the result of irrational motivational factors. The work of Katona (1975) highlighted that people's beliefs about the economy also mediate their savings. According to Modigliani's life cycle theory, individuals can distribute their income throughout their lives, providing financial security for possible difficult times and their pensions, so people save after retirement to secure consumption, leading to a well-known welfare and then declining wealth profile (Modigliani 1986). However, as early as in the 1970s, researchers have found that the observed age-consumption profiles differ from those predicted by pure life-cycle theory, but the theory is well expandable. According to their research, people's savings rate increases with age, and cohort effects and income-specific differential mortality did not reverse the age-saving profile (see, inter alia, Mirer 1979, Börsch-Supan 1992).

\section{LIVING STANDARDS OF HUN- GARIAN HOUSEHOLDS WITH REGARD TO THE ELDERLY}

According to the Hungarian Central Statistical Office publication on the living standards of households in 2019, the highest incomes were among those aged 55-64, those with higher education and the economically active (HCSO 2019). The gross per capita income of households increases with the age of the reference person. Gross income per capita was the highest in the 55-64 age group, amounting to 2 million 264 thousand HUF per year in $2019,13.7 \%$ more than in 2018 (Figure 1.). 
Figure 1. Annual gross inocomes per capita by age groups, schooling and economic activity

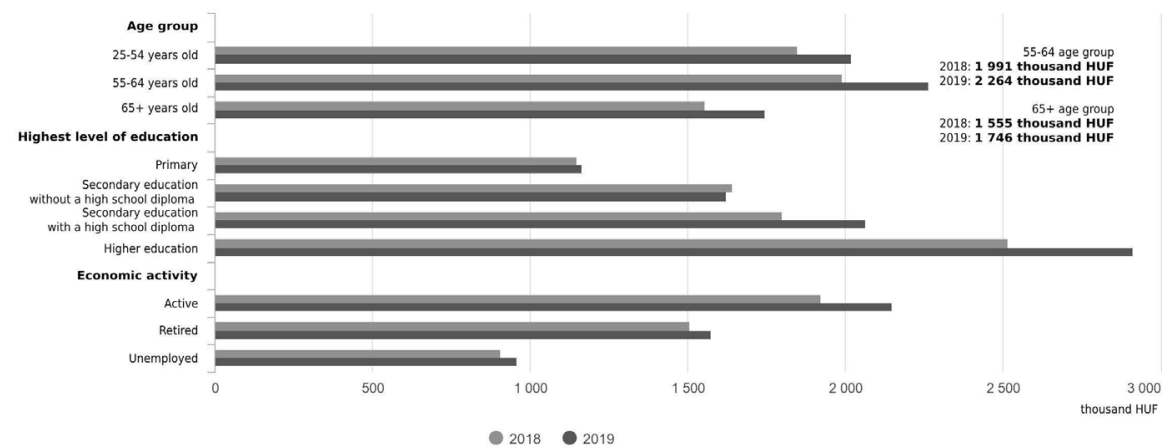

Source: HCSO 2019 (online)

The gross income per capita of retired households increased by $4.6 \%$ in 2019 compared to the previous year, amounting to $1,574,000$ HUF. The annual amount of social income per capita reached 477 thousand HUF. In terms of composition, the largest share $(81.3 \%)$ was accounted for by pensions and pension-like benefits. In 2019, the average gross Hungarian salary was 406,400 HUF, while the average pension was 134,947 HUF.

The income situation of households also varies considerably across regions. In 2019, the region with the highest income per capita was Budapest, where the average annual income per capita was 2,641,000 HUF, while the gross income per capita of the lowest-income households in the Northern Great Plain was only 1,658,000 HUF. The average income per capita of the Budapest region is 1.3 times the national average, while the incomes of households in the Northern Great Plain region are $17.3 \%$ lower than the national average. The size of incomes also follows the settlement hierarchy: larger settlement, higher gross income per capita.

A peculiarity of the consumption structure of pensioners is that the weight of housing maintenance expenditures per capita is higher in their households, as their households usually have fewer than average people, often only 1 person, so fixed costs are not distributed (HCSO 2019; Figure 2). Furthermore, it follows from the age specificity that the retired age group has the highest health expenditure compared to other household types. In their case, health care expenditures amounted to almost 160 thousand forints per year, of which almost 96 times the national average, 96,400 forints were spent on medicines. Per capita personal expenditure of retired households amounted to 1,410,000 HUF, $1.3 \%$ more at current prices than a year earlier.

Figure 2. Structure of household expenditure, by household categories

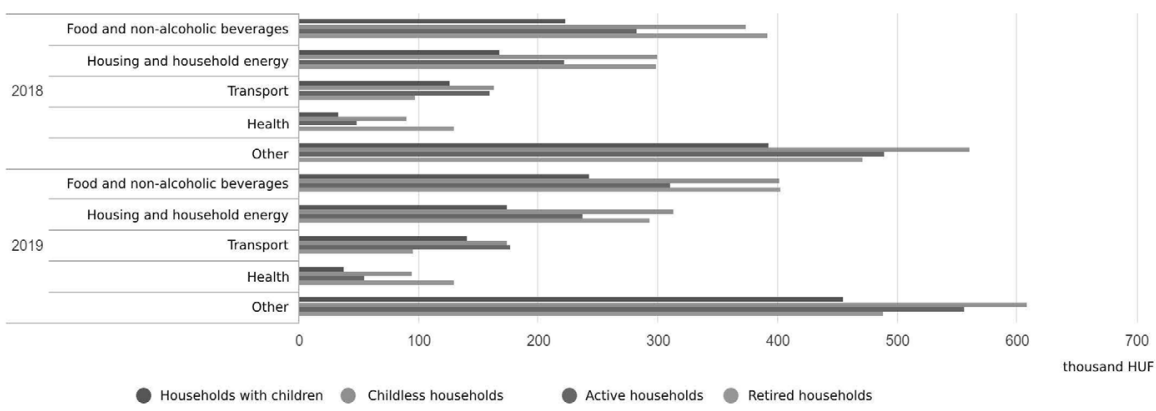

Source: HCSO 2019 (online)

24 MARKETING \& MENEDZSMENT 2021. KÜLÖNSZÁM 2. Időskori pénzügyi és befektetési döntések 
Pensioner households spent 402,600 HUF on food and non-alcoholic beverages, while 293,500 HUF was spent on housing and household energy. 95,700 HUF was earmarked for transport, 130,000 HUF for health care expenses and 488,300 HUF for other expenses. For comparison, in 2016, Hungarian retirees spent $28 \%$ for services, followed by food with $27 \%$ (HCSO 2016). Third place went to the other articles category with more than $19 \%$, which also includes medicines and other medicinal products. The elderly spent an additional $10 \%$ on overheads and $8 \%$ on spirits and tobacco, while only $5.5 \%$ of their income went to the purchase of durable consumer goods and no less than $2 \%$ to their clothing. For the same, the non-retired population sacrificed for alcohol and cigarettes an average of $3.5 \%$ and $2 \%$ more, respectively.

Older generations today see their identity as well as their defined role in society differently than previous generations (Szarka 2014, 27). According to Guido $(2018,258)$, in recent years, elderly consumers $(60+$ years old) have shown dramatic changes in the products they purchase, both by type and quantity. Gone are the days of old stereotypes depicting senior consumers as poor, sick, inactive, who are barely willing to spend their money and don't want to try new things, as older people tend to be richer, healthier, more active and more inclined to prefer quality. In addition to all this, of course, stereotypical shopping characteristics in old age can be identified (e.g., buying regular brands, favoring convenience stores, etc.)

\section{DATA AND DESCRIPTIVE STA- TISTICS}

A nationally representative personal survey with 500 respondents was conducted in February 2020 on a targeted sample of the Hungarian population aged 50-70. The survey is representative of the Hungarian population aged $50-70$ by gender, age groups (5-year intervals) and region of residence. The survey was prepared with the support of the EFOP-3.6.1-16-2016-00004 project "Comprehensive developments at the University of Pécs for the implementation of intelligent specialization" (Basic study: Hegedüs - Töröcsik 2020). The aim of the research was to understand the problems of aging and aging societies, including the relationship of elderly age groups to their age, quality of life and environment, and especially to their (subjectively perceived) changes in shopping habits. The fieldwork of the survey was carried out by a specialized company with a network of interviewers. Data collection was carried out by random walking within the settlement, based on the last birthday within the household. Table 1 shows the main demographic characteristics of the respondents.

This query database was used in our study for further analysis. In the analysis, we used cluster formation to identify groups with different consumption changes in the 50-70 age group. The subjective assessment of the change in consumption was made by the respondents recalling a period of 10 years. After examining the internal distances between potential clusters (by hierarchical cluster analysis, Ward method, based on square Euclidean distance, interpretation of aggregation table and dendogram), we used K-means cluster analysis to determine which cluster formation procedure is accepted in the social sciences. Data were processed using IBM SPSS 25 and Microsoft Office Excel 2016 programs. 
Table 1. Demographic data of the old generation

\begin{tabular}{|c|c|c|}
\hline & $\%$ & $\%$ \\
\hline Gender & Marital stat & \\
\hline male & $46.1 \%$ single & $38.6 \%$ \\
\hline female & $53.9 \%$ in partnership & $61.4 \%$ \\
\hline Highest level of education & \multicolumn{2}{|l|}{ Age } \\
\hline Primary (up to 8 years of elementary school) & $10.9 \% 50-54$ age group & $24.3 \%$ \\
\hline $\begin{array}{l}\text { Vocational training, vocational secondary } \\
\text { school }\end{array}$ & $40.7 \% 55-59$ age group & $22.1 \%$ \\
\hline Vocational high school graduation & $18.5 \% 60-64$ age group & $26.5 \%$ \\
\hline High school & $9.3 \% 65-70$ age group & $27.1 \%$ \\
\hline Technical school & $6.5 \%$ Region & \\
\hline Bachelor's degree & $10.6 \%$ Central Hungary & $28.3 \%$ \\
\hline Master's degree & $3.2 \%$ Central Transdanubia & $11.1 \%$ \\
\hline no respond & $0.2 \%$ West Pannon & $10.5 \%$ \\
\hline Economic activity & South Transdanubia & $9,9 \%$ \\
\hline Active blue-collar worker & $34.8 \%$ Northern Hungary & $12.0 \%$ \\
\hline Active white-collar worker & $16.0 \%$ Northern Great Plain & $14.9 \%$ \\
\hline Retired & $40.9 \%$ Southern Great Plain & $13.3 \%$ \\
\hline Unemployed & $1.4 \%$ Settlement & \\
\hline Homemaker & $1.0 \%$ Budapest & $16.1 \%$ \\
\hline Pre-retirement assistance & $2.0 \%$ city with county rights & $22.3 \%$ \\
\hline Other inactive status & $3.9 \%$ city & $32.9 \%$ \\
\hline Monthly income level & village & $28,7 \%$ \\
\hline $\begin{array}{l}\text { We make a living by it very well and we can } \\
\text { spare money. }\end{array}$ & $7.3 \%$ State of health & \\
\hline $\begin{array}{l}\text { We make a living, and we can spare little } \\
\text { money. }\end{array}$ & $\begin{array}{l}\text { I am not limited by my } \\
38.6 \% \text { health condition in anyt- } \\
\text { hing }\end{array}$ & $62.8 \%$ \\
\hline $\begin{array}{l}\text { Just enough to make a living by it, and we can't } \\
\text { spare. }\end{array}$ & $\begin{array}{l}45.9 \% \text { My way of life is slightly } \\
\text { limited by my health con- }\end{array}$ & $33.5 \%$ \\
\hline We have living problems regularly. & $5.0 \%$ dition & \\
\hline no respond & 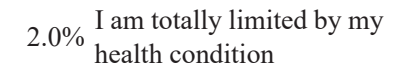 & $3.7 \%$ \\
\hline The number of people & $\mathrm{g}$ in the same household & \\
\hline 1 & $23.7 \% 4$ & $9.1 \%$ \\
\hline 2 & $47.1 \% 5-7$ & $4.3 \%$ \\
\hline 3 & $15.7 \% 10+$ & $0.2 \%$ \\
\hline
\end{tabular}

Source: edited by the authors $(n=500)$ 


\section{SAVING FOR OLD AGE ACCOR- DING TO AGE AND THE ABI- LITY TO SAVE}

Using the database, we wanted to map the spending habits of the 50 plus age groups and their financial awareness of their disposable income. During the study, we classified the respondents into clusters based on the change in spending in the consump- tion categories of the Hungarian Central Statistical Office.

Respondents had to answer the question ("How did your spending change for the following product groups compared to your life 10 years ago? Example 1. Food and non-alcoholic beverages") on a 5-point scale, where 1 meant that one spends much less on it, a 3 that it hasn't changed and a 5 that one spends a lot more on it. During the study, 5 well-separable cluster groups were formed (Table 2).

Table 2. Changes of the spendings of cluster groups over a ten-year period

\begin{tabular}{l|c|c|c|c|c|c}
\hline \multicolumn{1}{c|}{ Cluster groups } & $\mathbf{1}$ & $\mathbf{2}$ & $\mathbf{3}$ & $\mathbf{4}$ & $\mathbf{5}$ \\
\hline \multicolumn{1}{c|}{ Persons } & 54 & 268 & 61 & 55 & 62 \\
\hline \multicolumn{1}{c|}{ Consumption cateories } & \multicolumn{5}{c}{ Deviation from average } \\
\hline 1. Food and non-alcoholic beverages & -0.038 & 0.273 & 0.114 & -1.528 & -0.007 \\
\hline 2. Alcoholic beverages & -0.406 & 0.391 & -0.261 & -1.513 & 0.163 \\
\hline 3. Tobacco products & -0.053 & 0.466 & -0.941 & -1.304 & 0.058 \\
\hline 4. Clothing and shoes & -0.440 & 0.362 & 0.731 & -1.496 & -0.712 \\
\hline 5. Home maintenane and household energy & 0.402 & 0.067 & 0.887 & -1.345 & -0.426 \\
\hline 6. Furnishings and renovations & -0.102 & 0.259 & 0.843 & -1.525 & -0.642 \\
\hline 7. Health & 0.600 & -0.113 & 0.622 & -1.064 & 0.231 \\
\hline $\begin{array}{l}\text { 8. Transportation (car, public transport season } \\
\text { tickets) }\end{array}$ & 0.100 & 0.175 & 0.460 & -0.849 & -0.614 \\
\hline 9. Communication (mobile phone, landline, TV) & 0.446 & -0.033 & 1.069 & -0.976 & -0.517 \\
\hline 10. Culture and entertainment & -1.152 & 0.367 & 0.491 & -1.480 & 0.103 \\
\hline 11. Education & -1.048 & 0.477 & -0.122 & -1.129 & -0.127 \\
\hline 12. Catering & -1.342 & 0.363 & 0.694 & -1.713 & 0.264 \\
\hline 13. Travel and holiday & -1.374 & 0.278 & 0.860 & -1.302 & 0.152 \\
\hline 14. Look (hairdresser, cosmetician, makeup, nails) & -0.667 & 0.233 & 0.928 & -1.567 & -0.102 \\
\hline & & & & \\
\hline
\end{tabular}

Source: edited by the authors (questioning respondents aged 50-70); "How did your spending change for the following product groups compared to your life 10 years ago?"

Overall, the results show that the respondent's spending did not really change drastically compared to their lives 10 years ago, or - as the answer is based on subjective memories and feelings - they did not necessarily perceive the changes. As a large number of respondents also reached the retirement age, we also got some picture of their change in living standards. If we take into account the fact that our retirement income in old age is far below the income of active, working years (example: the average gross salary in 2019 was 406,400 HUF, while the average pension was 134,947 HUF), we can assume that if the significant decrease in income did not affect consumption habits, so there was no drastic change in the standard of living, in that case old-age incomes can be supplemented by savings made in active age.

The group with the largest number of items indi- 
cates a moderate decline over the years, but this is not necessarily due to an increase in their age (and thus to changes in their life situation), but more likely to be more influenced by general economic changes. However, this question was not used in the interview. Although the clusters are well separable, the cluster of "Moderate Consumers" (who have little perception of change) takes the weight in proportions, so the change itself is not necessarily well grasped through the clusters. Nevertheless, in some cases the respondents reported a perceptible change, so the following cluster groups can be discussed:

1 - Health spending (11\%): the members of the group are mainly women, live in Budapest, are pensioners and are just making a living from their income, but they feel less disadvantaged due to their financial situation. Compared to the others, the members of this group live in the highest proportion alone and $15 \%$ of them also feel disadvantaged because of this. They are pessimistic that family members, friends, or neighbors would help them if they needed this and maybe this is the reason why they try less to get involved in the things around them.

They spend more on things related to their health, but also on communication, housing and transportation. In contrast, they spend far less on any form of entertainment now, compared to their lives 10 years ago, than on other groups (the only exception being the group of barely consumers). The second is one of the groups whose members most believe that their spending habits have changed in recent years. On the other hand, members of this group testified in the highest proportion that they pay much more attention to their spending today than before and are the most sales-oriented. They have testified most of the time that they are giving up buying more products these days because they pay more attention to their environment.

2 - Moderate consumers (54\%): there was a small increase in spending in all areas, with the exception of healthcare. They are mainly still an active group of workers with a medium income situation. They perceive the least disadvantages in their lives and compared to other people they are the most satisfied with their physical activity. They are also satisfied with their quality of life and this group agreed to the greatest extent with the statement that they enjoy their lives as a whole. They act in company and have strong family and friendships. They are least disturbed by the external signs of aging and health status, as well as their appearance, subjectively the group that feels the youngest. In terms of their real age, most early 50 s belong to this group, but there are many of them in the 60-64 age group as well.

Members of this group felt, for the most part, that their spending habits had not changed and that they would least spend much more than before. More than $50 \%$ of them testified that they did not have to give up buying products at all for health reasons or because of their financial situation.

3 - Communication-oriented (12\%): Members of this group have spent mainly on communication for more than 10 years, while "abandoning" their harmful passions such as alcoholic beverages or tobacco products. However, they spend less on education - probably because at this time their children flew out of the home nest (the group is mostly made up of 55-59 year olds) and perhaps increased as a result of entertainment (travel, hospitality, culture, dressing, furnishings) in their expenditure. They are predominantly even economically active, able to set aside a little of their income, and enjoy good health. Disadvantages are less perceived in their lives, mainly only because of their age, but not to a great extent. They consider themselves healthier and more active compared to their age group. In terms of quality of life, they are most satisfied with their lives and most satisfied with their own home. Nearly $85 \%$ of them try to stay involved in different things, live a social life, and mostly take life the way it comes and try to get the best out of it, and feel happier than other people. In contrast, they are most disturbed by the external signs of aging.

They do not necessarily perceive that their spending habits have changed in recent years and they give up few products for health, material or environmental reasons.

The members of the group agreed to the greatest extent with the statement that their way of thinking is modern and that they are monitoring the emergence of new products that interest them.

4 - Barely consumers (11\%): the members of this group are mostly men, have a poor income situation and most of them do not live in a relationship. In all areas, there is a strong decline in their spending and members came mainly from the over- 65 age group. They feel disadvantaged because of their financial situation and because they live alone. As a result of all this, they are the group that is least satisfied with their quality of life and who least expect their family members or friends to help if they are in trouble. They are overwhelmingly unhappy with what they are doing and feeling more unhappy than other people. 
This group felt, for the most part, that they needed to tighten their spending heavily and therefore pay more attention to their spending. They give up products mainly for health and financial reasons and are least interested in new products appearing on the market.

5 - Those who allow small pleasures (12\%): the largest proportion are rural groups, and women, pensioners and, in terms of age, mainly over 60 (within this, the oldest age group surveyed in the largest proportion). Most of them live in a relationship and this group thought most neutrally about the issues that addressed their disadvantages. In terms of changes in their spending, they spend slightly more on alcohol, tobacco, entertainment, hospitality, recreation (but not transportation), and health than they did in their life situation 10 years ago.

However, less is spent on factors related to everyday life: including food, housing factors, appearance. They are not more satisfied with their lives than others, but they consider themselves more active than their age and, on the whole, prefer to enjoy life, and do not consider themselves happier or more unhappy than others. They are satisfied with their social connections.

The largest proportion do not perceive any change in their shopping and spending habits in recent years, but they think they pay more attention to their spending. They mostly plan their customer tour based on the promotions and they are uninterested in the direction of new products, they buy their usual products. They think less that their way of thinking would be modern and also pay little attention to the external signs of aging.

The clusters we trained also show well that the costs of the 50-plus age group are also significant for the economy as a whole. The nature of their expenditures is diverse and there are a number of items that they could not afford from an average income funded by the pension scheme. The characteristics of the clusters also show that there is a positive relationship between financial awareness (planning spending, exploring actions) and age.

\section{CONCLUSIONS}

In our study, we sought to answer the question of how spending habits change in old age, and what composition of income is needed to maintain the standard of living achieved by spending. A review of the literature has shown that although the diffi- culties of aging societies and pension systems in national economies are well-known facts, savings and propensity for self-sufficiency in old age are particularly prevalent among the more educated and higher-income individuals. Furthermore, it can be stated that in order to be able to maintain our normal standard of living even after the active age, we do not yet generate savings at a young age. Due to the quality of living standards, we examined the development of incomes and expenditures of Hungarian households with the help of Hungarian Central Statistical Office's data, with special regard to the older age groups. Subsequently, in a 500-person survey of 50-70-year-old respondents, representative of the sample by gender, age, and place of residence, we examined how the spending habits of the respondents had changed over the past 10 years.

According to our results, respondents did not experience any drastic changes in their spending and consumption habits during the disputed period, according to their own admission. Since the study also covered a part of those reaching retirement age, where wage income was replaced by pension, which in each case means a drastic change in income, we can assume that there was no change in spending habits only if previously trained savings are taken into account. As a result of the study, 5 well-separable clusters were formed, which summarize the spending characteristics of the cluster members.

\section{LIMITATIONS}

Although clusters can be well distinguished, those who have little perception of change will carry weight in proportions, so change itself is not necessarily well understood through clusters. For this reason, we mark the use of an expanded set of questions as a future research direction for a deeper analysis of the problem. In our opinion, more accurate and less subjective results about changes in living standards can be obtained by including in the questionnaire the questions of income 10 years ago and income today. In addition, one can refine the results by asking about structural changes on the expenditure side, such as overdue, large-installment loans. Furthermore, quantitatively, there are many topics that are difficult to answer completely thoughtfully, and during the research we touched on questions that were perceived as discrete (age, change of financial situation) that people are reluctant to talk about. 


\section{REFERENCES}

Almenberg, J. \& Säve-Söderbergh, J. (2011), "Financial literacy and retirement planning in Sweden", Journal of Pension Economics and Finance, 10(4), 585-598 DOI:10.2139/ ssrn. 1809736

Atkinson, A. \& Messy, F.-A. (2011), “Assessing financial literacy in 12 countries: An OECD/ INFE international pilot exercise", Journal of Pension Economics and Finance, 10(4), 11, 657-665 DOI:10.1017/s1474747211000539

Banyár, J. (2019), „Az állami nyugdíjrendszer „születési” hibái és javításának fö iránya”, Pénzügyi Szemle, 2019(4), 540-553 DOI:10.35551/ PSZ 201944

Biljanovska, N. \& Palligkinis, S. (2018), "Control thyself: Self-control failure and household wealth", Journal of Banking \& Finance, 92, 280-294 DOI:10.2139/ssrn.2509080

Blaked, D. (2004), "The Impact of Wealth on Consumption and Retirement Behaviour in the UK", Applied Financial Economics. 14(8), 555-576 DOI:10.1080/0960310042000233863

Bloom, D. E., Canning, D., Mansfield, R. \& Moore, M. (2006), Demographic Change, social security, and savings. The National Bureau of Economic Research (NBER) Working Paper, No 12621., 41.

Boldizsár, A., Kékesi, Zs., Kóczián, B. \& Sisak, B. (2016), „A magyar háztartások vagyoni helyzete a HFCS felmérés alapján", Hitelintézeti Szemle, 15(4), 115-150

Börsch-Supan, A. (1992), "Saving and consumption patterns of the elderly. The German case", Journal of Population Economics, 5, 289-303 DOI: $10.1007 / \mathrm{bf} 00163062$

Choi, J. J. \& Robertson, A. Z. (2020), "What Matters to Individual Investors? Evidence from The Horse's Mounth", The Journal of Finance, 75(4), 1965-2020 DOI:10.1111/jofi.12895

Cobb-Clark, A. D., Kassenboehmer, C. S. \& Sinning G. M. (2016), "Locus of control and savings", Journal of Banking \& Finance, 73, 113 130 DOI: 10.1016/j.jbankfin.2016.06.013

Cocco, J., Gomes, F. \& Maenhout, P. (2005), "Consumption and portfolio choice over the life cycle", Review of Financial Studies, 18(2), 491-533 DOI:10.1093/rfs/hhi017

Dann, S. (2007), "Branded generations: Baby boomers moving into the seniors market", Journal of Product \& Brand Management, 16(6), 429-431 DOI: 10.1108/10610420710823799

Demirgüç-Kunt, A., Klapper, L. F. \& Panos, G. A.
(2016), "Saving for Old Age", World Bank Policy Research Working Paper, No. 7693, https:// ssrn.com/abstract $=2811340$

De Nardi, M., French, E. \& Jones, J. B. (2009), "Why Do the Elderly Save? The Role of Medical Expenses", Journal of Political Economy, University of Chicago Press, 118(1), 39-75. DOI:10.3386/w15149

Dushi, I. \& Honig, M. (2015), "How much do respondents in the health and retirement study know about their contributions to tax-deferred contribution plans? A cross-cohort comparison", Journal of Pension Economics and Finance, 14(3), 203-239 DOI:10.2139/ssrn.1510282

Fornero, E. \& Monticone, C. (2011), "Financial literacy and pension plan participation in Italy", Journal of Pension Economics and Finance, 10(4), 547-564 DOI:10.2139/ssrn.1810475

Guido, G., Pichierri, M., Pino, G. \& Conoci, R. (2018), "The segmentation of elderly consumers: A literature review", Journal of Customer Behaviour, 17(4), 257-278 DOI:10.1362/14753 $9218 \times 15445233217805$

HCSO (2016), A háztartások életszínvonala. Megtekintve: 2020. 01 20, Online elérhető: https://www.ksh.hu/docs/hun/xftp/idoszaki/ hazteletszinv/hazteletszinv16.pdf

HCSO (2019), A háztartások életszínvonala. Megtekintve: 2020. 01 20, Online elérhető: https://www.ksh.hu/docs/hun/xftp/idoszaki/ hazteletszinv/2019/index.html

Hegedüs, R.; Törőcsik, M. (2020), Ageing: az idősödö magyar lakosság (50-70 év) öregedéssel és vásárlási szokásaik megváltozásával kapcsolatos vizsgálata - országosan reprezentativ személyes megkérdezés eredményei $(n=500)$. Alaptanulmány. Pécs: PTE KTK. Letöltve: 2021.03.23. Online elérhető: https:// ktk.pte.hu/sites/ktk.pte.hu/files/images/szervezet/intezetek/mti/final ageing 500fos megkerdezes_alaptanulmany_2020.pdf

Horváthné Kökény, A., Széles, Zs. (2014), „Mi befolyásolja a hazailakosság megtakarítási döntéseit?", Pénzügyi Szemle, 2014(4), 457475.

Katona, G. (1975), Psychological economics. New York: Elsevier

Keynes, J. M. (1936), A foglalkoztatás, a kamat és a pénz általános elmélete (magyar kiad. 1965) Budapest: Közgazdasági és Jogi Könyvkiadó

Kuti, M., Schepp, Z. (2020), „Az idősödő társadalom és a kockázati attitüd", Pénzügyi Szemle 2020(4). 457-471. DOI:10.35551/ PSZ_2020_4_1

Lunt, P. K. \& Livingstone, S. M. (1991), "Psycho- 
logical, social and economic determinants of saving: Comparing recurrent and total savings", Journal of Economic Psychology, 12, 621-641. DOI:10.1016/0167-4870(91)90003-C

Lusardi, A. (2001), Explaining Why so Many People Do Not save. Center for Retirement Research at Boston College, 43.

Lusardi, A. \& Tufano, P. (2015), "Debt literacy, financial experiences, and overindebtedness", Journal of Pension Economics and Finance, 14(4), 332-368. DOI:10.3386/w14808

Lusardi, A. \& Mitchell, O. S. (2006), "Planning and financial literacy: How do women fare?" American Economic Review, 98(2), 413-417. DOI: $10.3386 / \mathrm{w} 13750$

Lusardi, A. \& Mitchell, O. S. (2007), "Financial literacy and retirement preparedness: evidence and implications for financial education", Business Economics, 35-44 DOI:10.2139/ ssrn.957796

Lusardi, A. \& Mitchell, O. S. (2011), "Financial Literacy around the World: An Overview", The National Bureau of Economic Research (NBER) Working Paper. 17107, 19.

Lusardi, A., Mitchell, O. S. \& Curto, V. (2014), "Financial literacy and financial sophistication in the older population", Journal of Pension Economics and Finance, 13(4), 347-366 DOI: $10.3386 /$ w15469

Mirer, T. W. (1979), "The wealth-age relation among the aged", Am Econ Rev, 69, 435-443

Modigliani, F. (1986), "Life Cycle, Individual Thrift, and the Wealth of Nations", American Economic Review, 76(3), 297-313

Ongena, S. \& Zalewska A. (2018), "Institutional and individual investors: Saving for old age", Journal of Banking \& Finance, 92, 257-268 DOI: $10.1016 /$ j.jbankfin.2017.10.012

Posza, A. (2019), Az öregkor és az öregedés tudományelméleti megközelítései. in: Kuti, M. (ed.): XIII. Pécsi Pénzügyi Napok - Új kihívások és lehetőségek: Pénzügykutatás, oktatás, szakma, Pécs: PTE KTK, 74-82

Sekita, S. (2011), "Financial literacy and retirement planning in Japan", Journal of Pension Economics and Finance, 10(4), 637-656 DOI: $10.1017 / \mathrm{s} 1474747211000527$

Starr, M. A. (2006), "Macroeconomic Dimensions of social Economics: saving, the stock Market and Pension systems", Departement of Economics Working Paper Series, American University. Washington, 2006(09), 20

Stiglitz, J. E. (2013), A válság utáni válságok. Világgazdaság online. 2013.01.09.

Szarka, K. (2014), Az 50+ generáció fenntartható fogyasztói magatartásának összehasonlitása svájci és magyarországi vizsgálatok alapján. PhD értekezés. Gödöllő: Szent István Egyetem van Rooij, M., Alessie, R., \& Lusardi, A. (2011), "Financial literacy and stock market participation", Journal of Financial Economics, 101(2), 449-472 DOI:10.3386/w13565

Wärneryd, K. E. (1989), "On the psychology of saving: An essay on economic behavior", Journal of Economic Psychology, 10(4), 515-541 DOI:10.1016/0167-4870(89)90041-X

Réka Hegedüs, PhD Student hegedus.reka@ktk.pte.hu

Klaudia Rádóczy, Assistant Lecturer radoczy.klaudia@ktk.pte.hu

University of Pécs Faculty of Business and Economics 